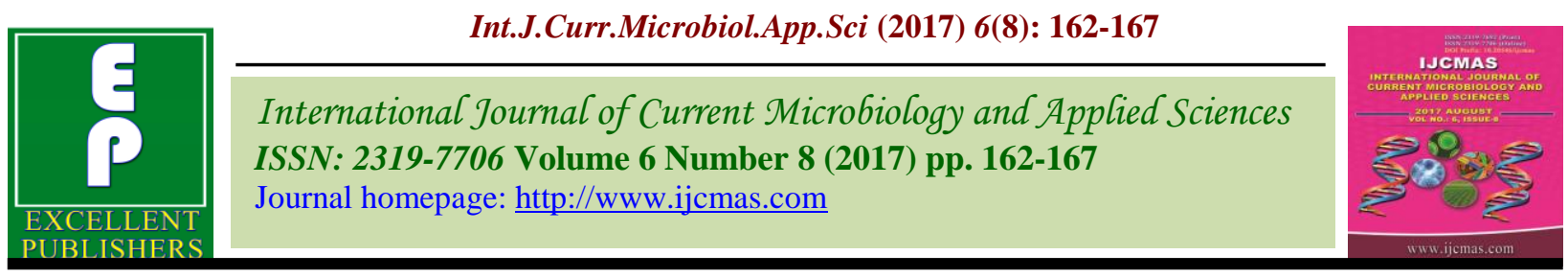

Original Research Article

https://doi.org/10.20546/ijcmas.2017.608.023

\title{
Yield Response of Drip Irrigated Cucumber to Mulch and Irrigation Regimes under Different Shading Net
}

\author{
Poornima*, S.B. Gadge and S.D. Gorantiwar \\ Department of Irrigation and Drainage Engineering, Dr. A. S. College of Agricultural \\ Engineering, Mahatma Phule Krishi Vidyapeeth, Rahuri - 413 722, India \\ *Corresponding author
}

\section{A B S T R A C T}

\section{Keywords}

Biometric

observation,

Cucumber

(Cucumis sativus

L.), Shade net,

Shading per cent.

Article Info

Accepted:

04 June 2017

Available Online:

10 August 2017
The field experiment was conducted at Instructional Farm of Department of Irrigation and Drainage Engineering, Mahatma Phule Krishi Vidyapeeth, Rahuri, to study the yield response of cucumber (cv. Gypsy) grown under shade net house to 35, 50, 75 per cent shading and Red shade net with $50 \%$ shading and in open field condition. The results were compared with the performance of the crop grown in open field (control) condition and also statistically analyzed. Irrespective of nutrient sources applied, the performance of crop grown inside the Red shade net was comparatively better than grown in open field conditions.

\section{Introduction}

In the horticultural production systems of India, the high temperatures and changing air moisture levels are prominent during the cultivation period. This causes stress in those crops whose production cycles coincide with these periods, and production is reduced because of setting and fruiting problems. The high solar radiation levels and temperatures experienced lead to high rates of plant water loss often causing irreversible burns or withering. The main purpose of shading is to reduce the temperature of the plant and so reduce this problem.

During the last decades, due to increased air temperature and intensity of solar radiation caused by climate changes, an increasing area of crops is being grown under shading materials of various types the advantages that the greenhouses can provide to the protected plants are numerous, among these advantages some can be highlighted including harvesting crops of the season, higher product quality, early crop maturity, seedling production, better control of diseases and pests, conservation of raw materials and water, planting of selected varieties and considerable increase in production.

The shading of crops results in number of changes on both local microclimate and crop activity. These changes on local microclimate modify $\mathrm{CO}_{2}$ assimilation and consequently crop growth and development. 


\section{Materials and Methods}

The experiment was conducted at Instructional Farm of Department of Irrigation and Drainage Engineering, Mahatma Phule Krishi Vidyapeeth, Rahuri during Feb - 2015 to May - 2015. The experiment was carried out in four shade net of a Green-white net houses with 35, 50, 75 per cent intensity $50 \%$ Red shade net and in full sunlight that is control treatment with split plot design. The hybrid variety "Gypsy" of cucumber was grown under shade net house and in control treatment. The size of the each shade net and the open field was $18 \mathrm{~m} \times 16 \mathrm{~m}$. The size of each plot was $2 \mathrm{~m} \times 3.9 \mathrm{~m}$. A $0.5 \mathrm{~m}$ buffer strip was provided between two beds to avoid lateral movement of water from one bed to another.

\section{Treatments and experimental details}

\section{Main-treatment}

S1: $35 \%$ Green-white shade net

S2: $50 \%$ Green-white shade net

S3: $75 \%$ Green-white shade net

S4: Red 50\% shade net

S5: Open (Control treatment) (Fig. 2 and 3).

\section{Sub-treatment}

$\mathrm{T}_{1}=$ Drip irrigation @ 120\% of ETc with plastic mulch.

$\mathrm{T}_{2}=$ Drip irrigation @ 120\% of ETc without plastic mulch.

$\mathrm{T}_{3}=$ Drip irrigation @ 100\% of ETc with plastic mulch.

$\mathrm{T}_{4}=$ Drip irrigation @ 100\% of ETc without plastic mulch.

$\mathrm{T}_{5}=$ Drip irrigation @ 80\% of ETc with plastic mulch.
$\mathrm{T}_{6}=$ Drip irrigation @ 80\% of ETc without plastic mulch.

$\mathrm{T}_{7}=$ Drip irrigation @ 60\% of ETc with plastic mulch.

$\mathrm{T}_{8}=$ Drip irrigation @ 60\% of ETc without plastic mulch.

\section{Climatological data}

The meteorological data on important weather parameter during the crop growth period were collected on daily basis from the meteorological observatory situated at the Instructional Farm of Department of Irrigation and Drainage Engineering.

The data included maximum and minimum temperature, minimum and maximum relative humidity, actual sunshine hour and daily wind speed etc.

On the basis of climatological data, daily water requirement for cucumber was estimated. Irrigation with $120 \%, 100 \%, 80 \%$, $60 \%$ of $\mathrm{ET}_{0}$ was given on daily basis through drip system (Tribhuvan et al., 2010). Gator pump was used to inject the fertigation in drip system as per the requirement of cucumber. Fruits were harvested at their marketable size.

\section{Biometric observations recorded}

For recording various biometric observations sample plants were selected from each treatment and tagged for their identification. The observations such as average diameter of fruit, average length of fruit, average weight of fruit, days to 50 per cent flowering, average length of vine at last harvest, number of fruits per vine, total yield per plot were recorded throughout the growing season. The fruit yield of cucumber in shade net house was compared with that in open field conditions and correlated with other data. 


\section{Results and Discussion}

The experimental findings obtained from the present study have been discussed in following heads:

\section{Water requirement}

Total water requirement of cucumber crop was $493.89 \mathrm{~mm}$ for the entire season. Figure 1 reveals that, the net water requirement for cucumber crop varied from $1.9 \mathrm{~mm}$ to $4 \mathrm{~mm}$.

The higher water requirement in later growth period of cucumber may be due to higher temperature, sunshine hours and wind speed during the later growth period of cucumber crop.

\section{Average diameter of the fruit}

The highest diameter of fruit was recorded in treatment $\mathrm{S}_{4}(3.61 \mathrm{~cm})$ which were at par with treatment $S_{2}(3.56 \mathrm{~cm})$, followed by $S_{3}(3.34$ $\mathrm{cm})$ and $S_{1}(3.15 \mathrm{~cm})$. The lowest diameter of the fruit $(3.15 \mathrm{~cm})$ was recorded from treatment $\mathrm{S}_{5}$ i.e. control (Table 1 and Fig. 4A).

\section{Average length of fruit}

Average length of fruit was non-significantly affected by shading percentage of shade net (Table 1 and Fig. 4B).

\section{Average weight of fruit}

The maximum average weight $(170.87 \mathrm{~g})$ was recorded under shade net with 75 per cent shading, followed by average weight (167.15 g) recorded from 50 per cent shading at par to 35 per cent shading (165.32 g).

The lowest average weight (82.81 g) was recorded from control treatment (Table 1 and Fig. 4C).

Table.1 Effect of shading percentage of shade net on yield and quality of cucumber

\begin{tabular}{|l|l|l|l|l|l|l|l|}
\hline \multicolumn{7}{|c|}{ Effect of shading percentage of shade net on growth and yield of cucumber } \\
\hline Treatment & $\begin{array}{l}\text { Days to } \\
\mathbf{5 0 \%} \\
\text { flowering }\end{array}$ & $\begin{array}{l}\text { Average } \\
\text { diameter } \\
\text { of fruit }\end{array}$ & $\begin{array}{l}\text { Average } \\
\text { length of } \\
\text { fruit }\end{array}$ & $\begin{array}{l}\text { Weight } \\
\text { of fruit } \\
\text { (g) }\end{array}$ & $\begin{array}{l}\text { Length of } \\
\text { vine at last } \\
\text { harvesting }\end{array}$ & $\begin{array}{l}\text { Number } \\
\text { of fruits } \\
\text { per vine }\end{array}$ & $\begin{array}{l}\text { Yield per } \\
\text { plot (kg) }\end{array}$ \\
\hline S1 & $34.17^{\mathrm{d}}$ & $3.23^{\mathrm{a}}$ & 14.96 & $176.55^{\mathrm{c}}$ & $2.99^{\mathrm{a}}$ & $8.63^{\mathrm{b}}$ & 1.49 \\
\hline S2 & $39.00^{\mathrm{c}}$ & $3.56^{\mathrm{c}}$ & 15.06 & $159.70^{\mathrm{b}}$ & $3.46^{\mathrm{b}}$ & $9.50^{\mathrm{c}}$ & 1.47 \\
\hline S3 & $43.67^{\mathrm{b}}$ & $3.34^{\mathrm{b}}$ & 14.73 & $160.98^{\mathrm{c}}$ & $3.82^{\mathrm{c}}$ & $11.73^{\mathrm{d}}$ & 1.51 \\
\hline S4 & $32.45^{\mathrm{d}}$ & $3.61^{\mathrm{c}}$ & 15.18 & $207.14^{\mathrm{d}}$ & $4.74^{\mathrm{d}}$ & $12.68^{\mathrm{d}}$ & 1.52 \\
\hline Open field & $47.17^{\mathrm{a}}$ & $3.15^{\mathrm{a}}$ & 14.43 & $143.63^{\mathrm{a}}$ & $2.31^{\mathrm{a}}$ & $7.54^{\mathrm{a}}$ & 1.40 \\
\hline SE \pm & 0.17 & 0.06 & 0.18 & 6.24 & 0.10 & 0.39 & 0.04 \\
\hline CD & 0.55 & 0.20 & NS & 20.35 & 0.32 & 1.28 & $\mathrm{NS}$ \\
\hline
\end{tabular}

Fig.1 Water requirement of cucumber crop during growth period

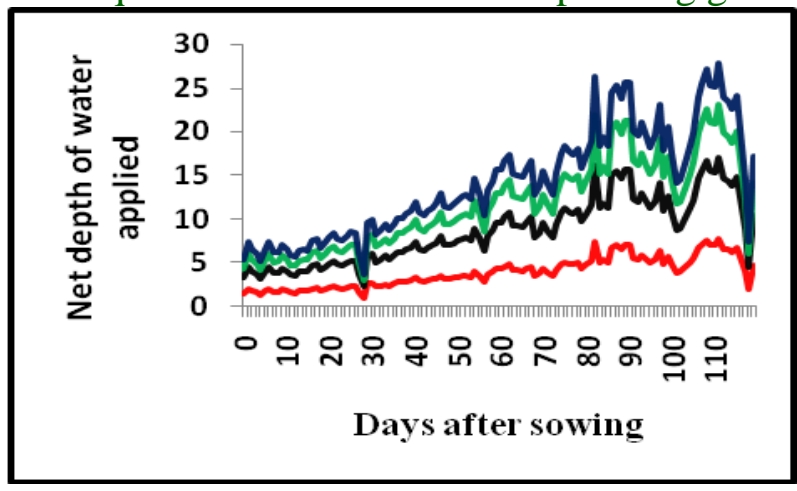


Fig.2 Internal view of shade net

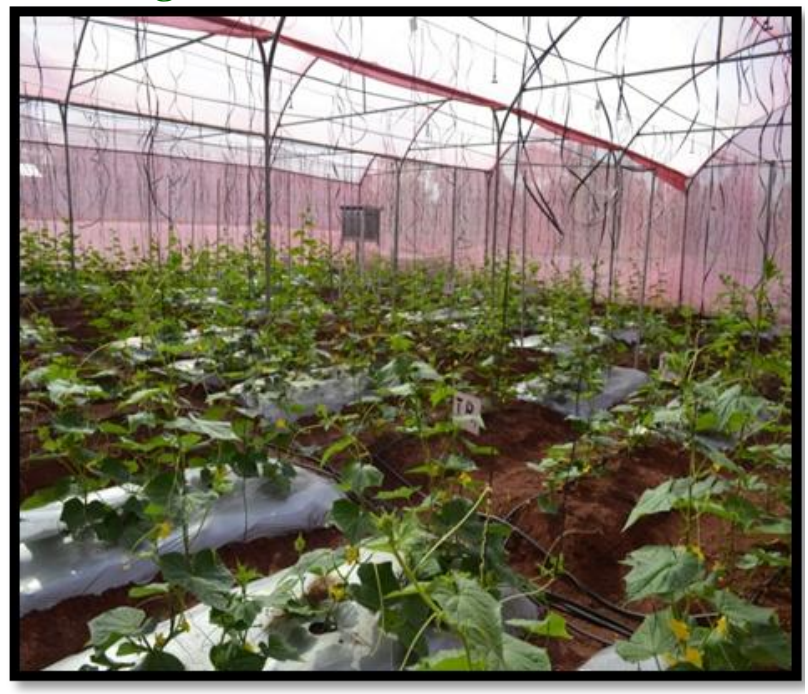

Fig.3 Fruit setting stage of cucumber

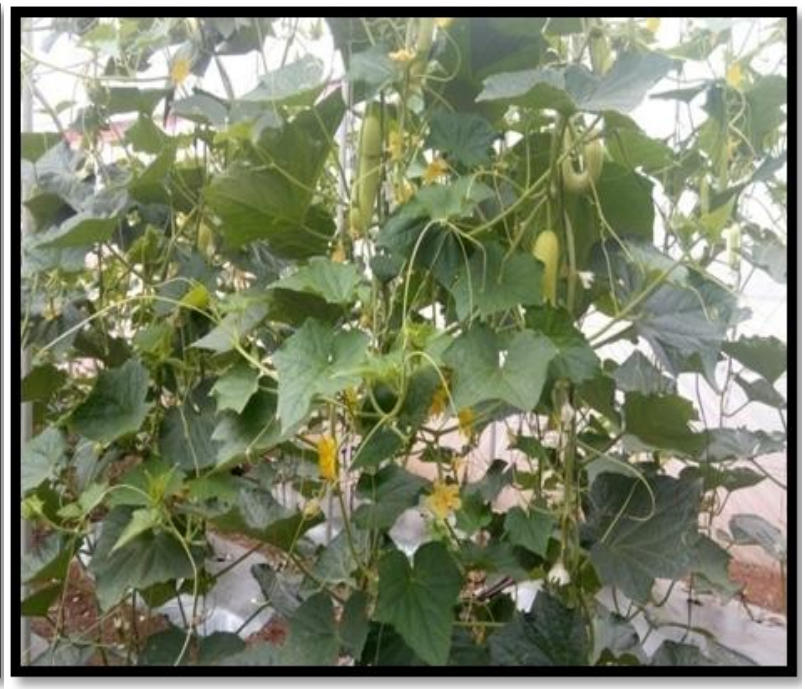

Fig.4 Effect of shading percentage of shade net on biometric observations

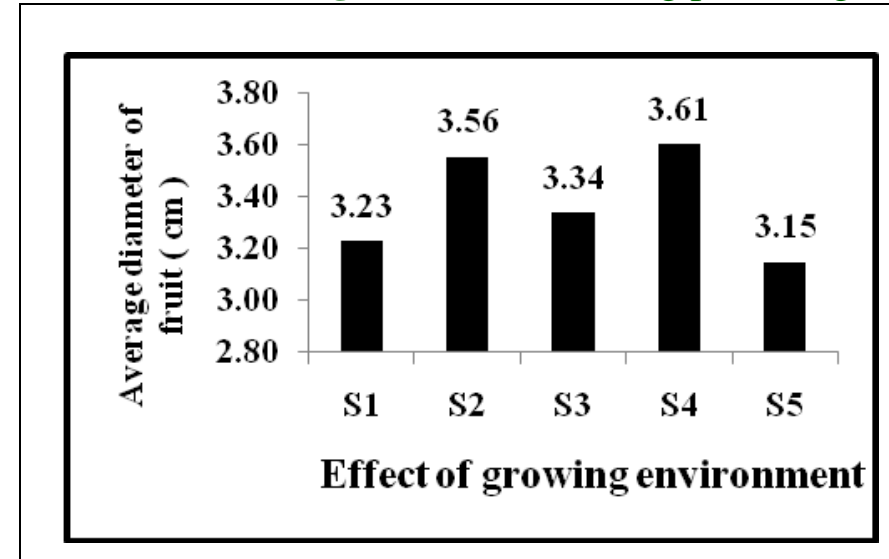

Fig.(A) Average diameter of fruit

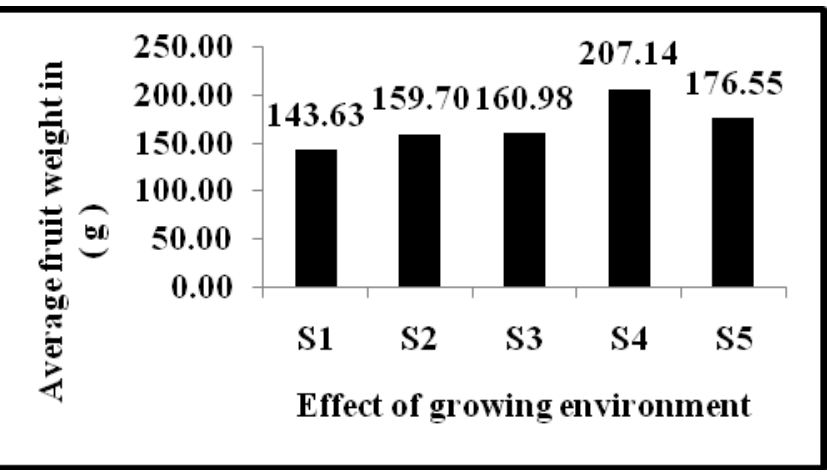

Fig.(C) Average weight of fruit

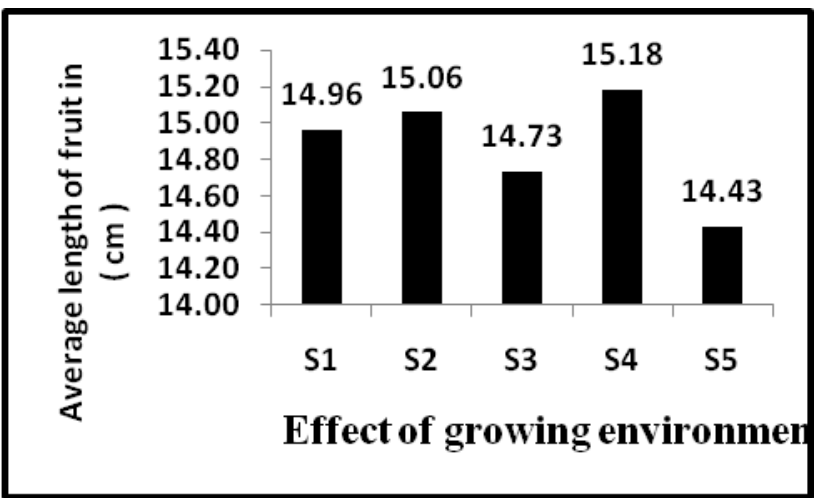

Fig.(B) Average length of Fruit

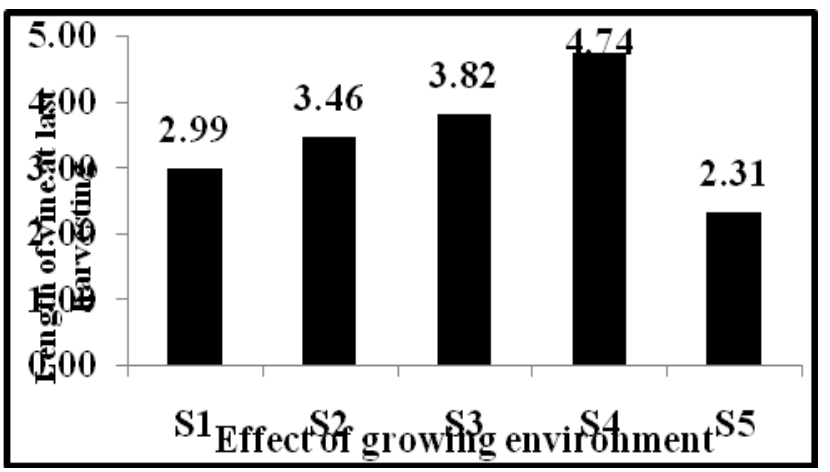

Fig.(D) Length of vine at last harvesting 


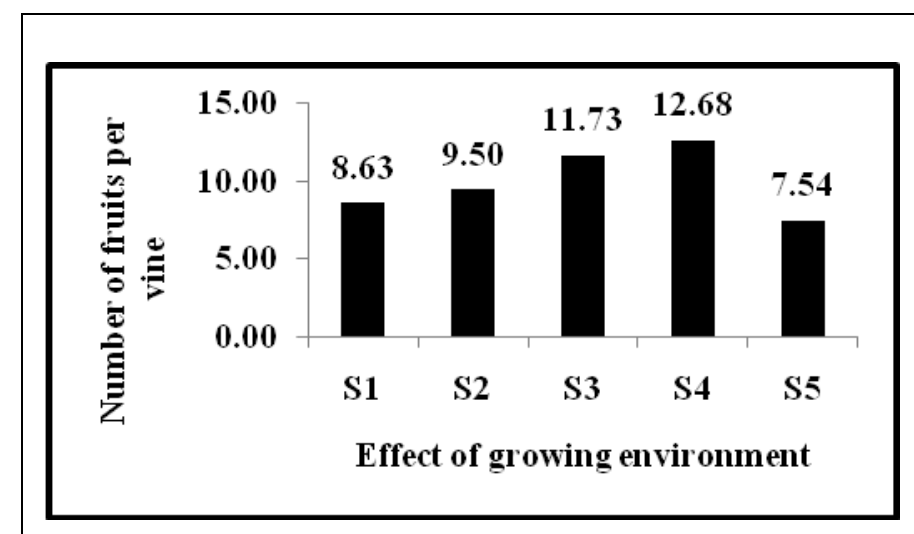

Fig.(E) Number of fruits per vine

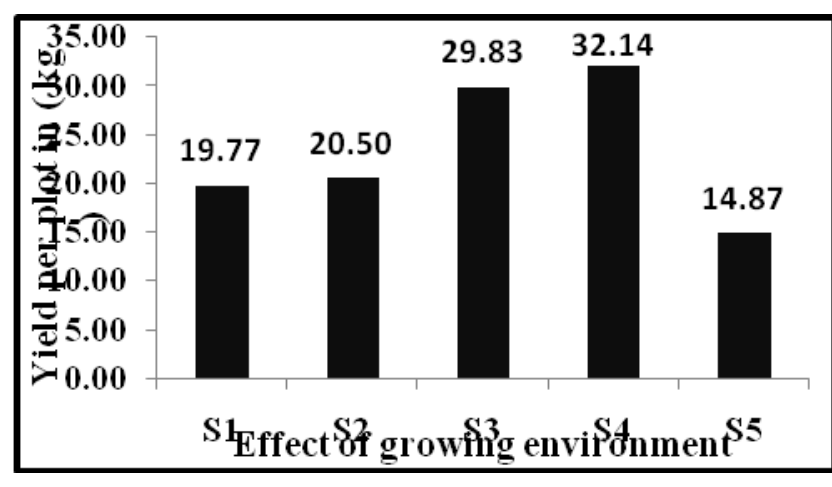

Fig.(F) Yield of fruit per plot

\section{Length of vine at last harvest}

The maximum length of vine $(4.74 \mathrm{~m})$ was observed in treatment $\mathrm{S}_{4}$, which was followed by treatment $\mathrm{S}_{3}(3.82 \mathrm{~m}), \mathrm{S}_{2}(3.46 \mathrm{~m}), \mathrm{S}_{1}$ $(2.99 \mathrm{~m})$. The minimum length of vine $(2.31$ $\mathrm{m}$ ) was observed in treatment $\mathrm{S}_{5}$ i.e. control treatment. This might be due to unfavorable environment in open field (control) on account of higher temperature that has adverse effect on growth and development of the crop (Table 1 and Fig. 4D).

\section{Number of fruits}

The cucumber grown under shade house condition, on an average produced higher number of fruits per vine. The treatment $\mathrm{S}_{4}$ (12.68) was significantly superior to $\mathrm{S}_{3}$ (11.73) and all other treatment.

The minimum number of fruits per vine was recorded in open field condition (7.54) i.e. treatment $\mathrm{S}_{5}$ (Table 1 and Fig. 4E).

\section{Yield of fruits}

The maximum yield of fruit per plot was observed in treatment $\mathrm{S}_{4}(32.14 \mathrm{~kg})$ which was significantly superior to all other treatments. Treatment $\mathrm{S}_{3}(29.83 \mathrm{~kg})$ followed by treatment $S_{2}(20.50 \mathrm{~kg})$ and $S_{1}(19.77 \mathrm{~kg})$. Minimum yield was observed in treatment $S_{5}$
$(14.87 \mathrm{~kg})$ i.e. in open field condition respectively (Table 1 and Fig. 4F).

It can be concluded that the irrespective of nutrient sources applied, mean air temperature of 40.34 to $24.660 \mathrm{C}$, mean relative humidity 91.80 to 30.53 per cent, mean sunshine hours 8.04 to 11.04 hrs, wind speed 1.72 to 6.55 $\mathrm{km} / \mathrm{hr}$ were found to be optimum for higher yield of cucumber $52.27 \mathrm{tha}^{-1}$ under Red shade net house with 50 per cent shading. The climatic condition proved adverse for cucumber cultivation under open field.

\section{References}

Elad, Y., Messika, Y., Brand, M., David, D.R. and Sztejnberg, A.2007. Effect of colored shade nets on pepper powdery mildew (Leveillula taurica). Phytoparasitica, 35(3): 285-299.

Patel, B.R., Gohil, K.B. and Veghasiya, P.M. 2003.Response of gladiator rose to fan pad cooled greenhouse under humid climate of Novsani. Proc. of All India Seminars on Potential and Prospects for Protective Cultivation, Organized by the Institute of Engineers,

Sganzerla, E. 1987. New agriculture: the fascinating art of cultivating with the plastics. Porto Alegre-RS: Triunfo Petrochemical. 297 p.

Shahak, Y., Gal, E., Offir, Y. and Ben-Yakir, 
D.2008. Photoselective shade netting integrated with greenhouse technologies for improved performance of vegetable and ornamental crops. ISHS International Workshop on Greenhouse Environmental Control and Crop Production in Semi-Arid Regions, Tucson AZ (C. Kubota and M. Kacira, Eds.). Acta Hort., 797: 75-80.

Tribhuvan, N.B. and Borude, S.P. 2010. Comparative study of yield and water use efficiency on cucumber grown under polyhouse, shade net and open field cultivation. B. Tech (Agri. Engg.) Thesis, Mahatma Phule Krishi Vidyapeeth, Rahuri, Ahmednagar, M.S. (India).

Zoran, I., Milenkovicl, L., Durovka, M. and Kapoulas, N. 2011. The effect of colour shade net on the green house climate and paper yield. Original Scientific Paper, 410(4): 201-210.

Patil, M.A. and Bhagat, A.D. 2014. Yield response of cucumber (Cucumis sativus L.) to shading percentage of shade net. Int. J. Agric. Engg., 7(1): 243-248.

\section{How to cite this article:}

Poornima, S.B. Gadge and Gorantiwar, S.D. 2017. Yield Response of Drip Irrigated Cucumber to Mulch and Irrigation Regimes under Different Shading Net. Int.J.Curr.Microbiol.App.Sci. 6(8): 162-167. doi: https://doi.org/10.20546/ijcmas.2017.608.023 